\title{
Keratoconus and corneal stability after radial keratectomy in the fellow eye: case report
}

\author{
Ceratocone e estabilidade corneana após ceratectomia radial no outro olho: relato de caso
}

\author{
Jacqueline Martins Sousa ${ }^{1}$, Flavio Eduardo Hiral ${ }^{1}$, Elcio Hideo Sato ${ }^{1}$
}

\begin{abstract}
Keratoconus has usually been described as bilateral but asymmetric disease. Corneal ectasia is one of the long-term complications of modern refractive surgery, especially those submitted to laser in situ keratomileusis (LASIK). We describe a patient with keratoconus in the right eye that was submitted to radial keratectomy (RK) in the left eye 19 years ago with no progression of the ectatic cornea and no complications related to the refractive surgery. Because unilateral keratoconus is rare, we believe that RK was performed on an already ectatic cornea (not clinically detected) or with fruste keratoconus. However, neither corneal ectasia progressed, nor ectasia was induced by RK in the fellow eye.
\end{abstract}

Keywords: Cornea/pathology; Corneal diseases; Corneal topography; Keratomileusis, laser in situ; Humans; Male; Case report

\section{RESUMO}

O ceratocone é descrito como uma doença bilateral porém assimétrica e vários dados na literatura comprovam que a ectasia corneana é uma das complicações de longo prazo da cirurgia refrativa moderna, especialmente do laser in situ keratomileusis (LASIK). Nós descrevemos um caso de uma paciente com ceratocone no olho direito e que foi submetida à ceratotomia radial no olho esquerdo há 19 anos, desde então sem sinais de progressão da ectasia corneana nem de complicações relativas à cirurgia refrativa. Como o ceratocone unilateral é raro, acreditamos que a cirurgia refrativa tenh a sido realizada num olho com ectasia corneana não detectada clinicamente ou com ceratocone frustro. Entretanto, a ectasia do olho direito não progrediu e também não houve sinais de ectasia no olho submetido à cirurgia refrativa nesse período de 19 anos de acompanhamento.

Descritores: Córnea/patologia; Doenças da córnea; Topografia da córnea; Ceratomileuse assistida por excimer laser in situ; Humanos; Feminino; Relato de caso

\section{INTRODUCTION}

Keratoconus (KC) is a non-inflammatory corneal disease characterized by progressive corneal protrusion, apical thinning, irregular astigmatism and central scarring at the cornea. It has usually been described as bilateral but asymmetric disease ${ }^{(1,2)}$. Clinical evidence of unilateral keratoconus may be as high as $41 \%$ of the population. However, only 1.8 - 4\% actually present diagnostic criteria for unilateral keratoconus when using the computerized corneal topography ${ }^{(3,4)}$.

Corneal ectasia is one of the long-term complications of modern refractive surgery, especially those submitted to laser in situ keratomileusis (LASIK). The main potential risk factors are preexisting corneal disease such as KC or mechanical instability as a consequence of weakened residual corneal stromal bed after $\operatorname{LASIK}^{(5)}$. Although previously described in the literature ${ }^{(6,7)}$, corneal ectasias have been less commonly seen in patients submitted to other types of refractive surgery such as photorefractive keratectomy (PRK) or radial keratotomy (RK).

We describe a patient with keratoconus in the right eye submitted to RK in the left eye who has been followed with no progression of the ectatic cornea and no complications following refractive surgery for 19 years.

\section{CASE REPORT}

A 42-year-old healthy woman was referred to our service for regular ophthalmic examination in 2000. Ocular history included left eye RK in 1994. According to the patient, RK was not performed in the right eye due to "lack of ideal conditions" (sic). At that time, the patient was fitted with rigid contact lens in the right eye. Biomicroscopic examination revealed right eye with signs of keratoconus and left eye with 8 healed radial keratotomy scars. Visual acuity was 20/20 with correction (contact lens) in the right eye and 20/25 without correction in the left eye.

The patient has been followed-up since then and the same signs of keratoconus were seen in the right eye with visual acuity of 20/25 with rigid contact lens. After 19 years of RK, her left cornea was stable and visual acuity was 20/25p with rigid contact lens. Corneal topographical maps of the right eye showed a typical pattern seen in patients with keratoconus with an asymmetric inferior corneal steepening in the vertical meridian. Figure 1 A shows the last topographical map of the right eye (2012) with comparison to a map taken in 2006 (Figure 1 B). No significant differences were seen between the two maps. Topographical maps of the left eye showed a flatter cornea after RK (Figure 2 A). Similarly to the right eye, no significant differences were seen between two maps (Figure 2 B) taken 6 years apart.

\section{DISCUSSION}

Corneal ectasia after refractive surgery is a rare event but can be very frustrating for both surgeon and patient. Randleman et al. ${ }^{(8)}$ reported an approximate incidence of 1 in 2,500 cases of keratectasia after LASIK.

In LASIK, it is believed that the creation of the corneal flap could be the major "triggering" factor of keratectasias. In the case of RK, he-
Submitted for publication: May 23, 2013

Accepted for publication: June 14, 2013

Study carried out at Department of Ophthalmology, Universidade Federal de São Paulo.

Physician, Department of Ophthalmology, Paulista School of Medicine, Federal University of São Paulo - UNIFESP, São Paulo (SP), Brazil.
Funding: No specific financial support was available for this study

Disclosure of potential conflicts of interest: J.M.Sousa, None; F.E.Hirai, None; E.H.Sato, None. Correspondence address: Jacqueline M. Sousa. Rua Botucatu, 821 - São Paulo (SP) - 04023-062 Brasil -E-mail: jacmsousa@gmail.com 
A

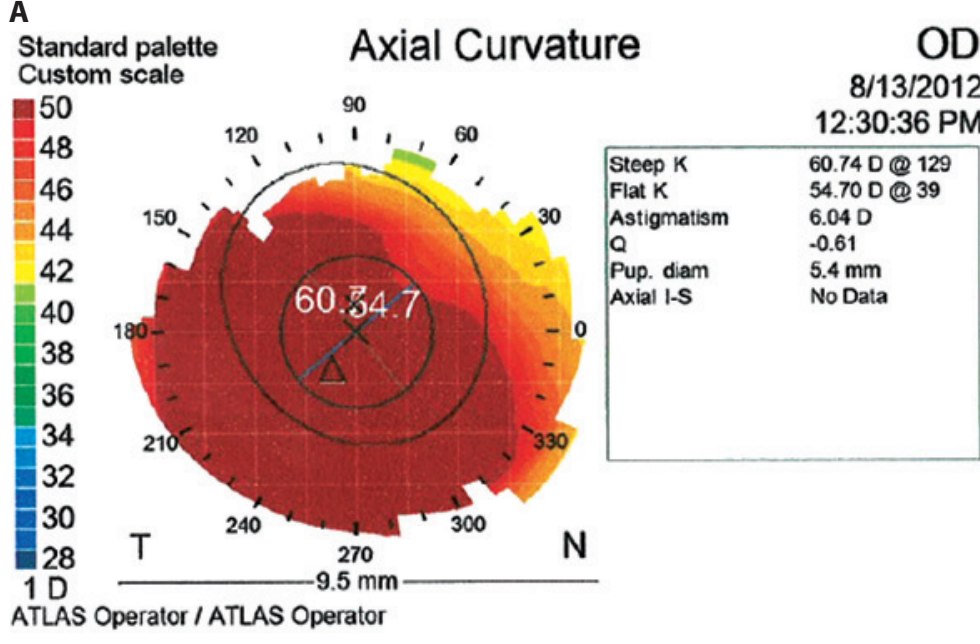

B

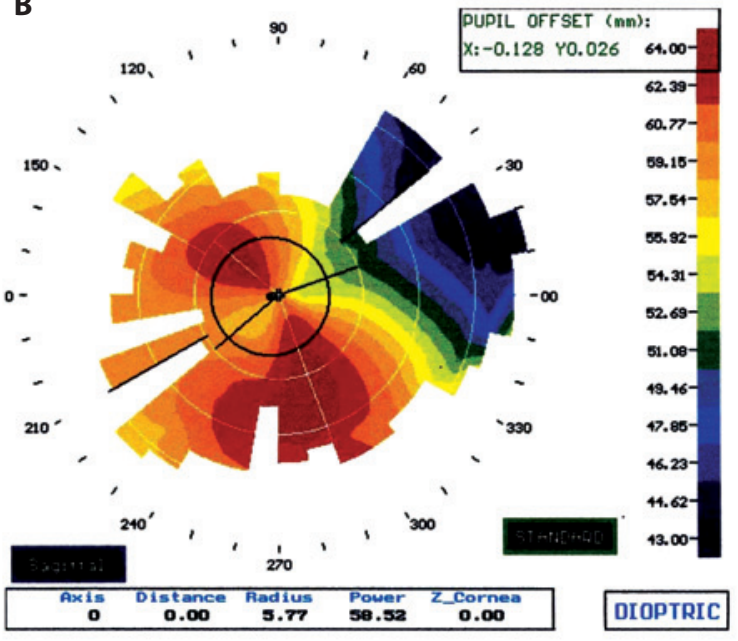

Figure 1. A) Corneal topography of the right eye in 2012. B) Corneal topography of the right eye in 2006.

A

\section{Standard palette \\ Custom scale}

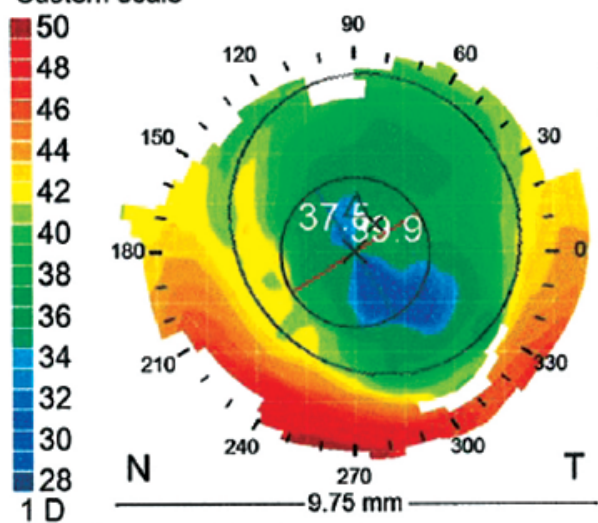

ATLAS Operator / ATLAS Operator
Axial Curvature

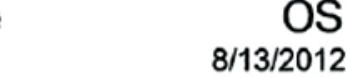

12:31:22 PM

$39.91 \mathrm{D} @ 32$

$37.47 \mathrm{D} @ 122$

$\begin{array}{ll}\text { Steep K } & 37.47 \mathrm{D} @ \\ \text { Flat K } & 2.44 \mathrm{D}\end{array}$

Q

Pup. diam

1.79

$5.9 \mathrm{~mm}$

Axial I-S

B

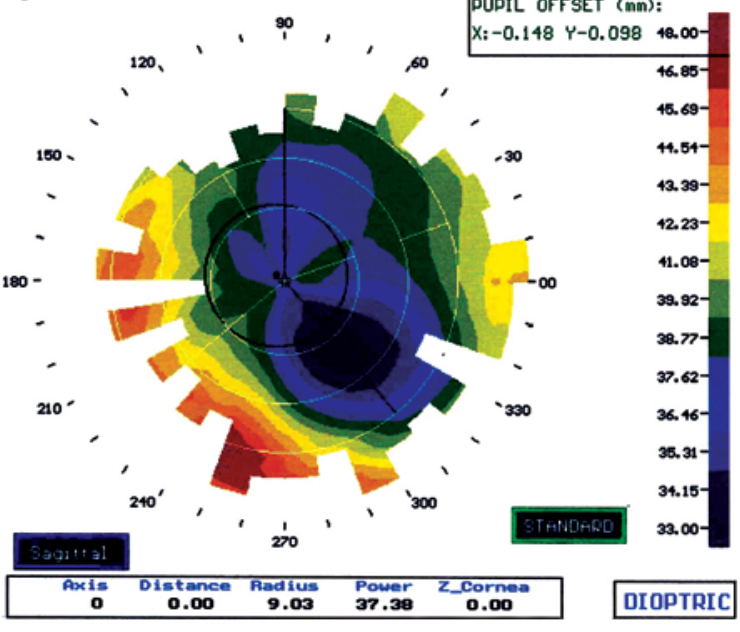

Figure 2. A) Corneal topography of the left eye in 2012. B) Corneal topography of the left eye in 2006.

xagonal keratotomy produces a hyperopic effect due to steepening of central cornea which theoretically may result in greater chance of developing iatrogenic keratoconus ${ }^{(6)}$. Nevertheless, Utine et al..$^{(9)}$, described radial keratotomy as a reasonable option for the rehabilitation of a selected group of keratoconus patients in the early or moderate stages, with improvement in the best spectacle corrected visual acuities, decrease of the preoperative myopic spherical refraction and flattening of the corneal curvature.

Unilateral keratoconus has a low incidence of around 4\%(3,4). Some studies showed that fellow eyes may show a certain low-expressivity morphologic feature of keratoconus, and that approximately $50 \%$ of clinically normal fellow eyes will progress to KC within 16 years and the greatest risk is during the first 6 years of the onset ${ }^{(10)}$. Because unilateral keratoconus is rare ${ }^{(3,4)}$, we believe that RK was performed in our patient on an already ectatic cornea (not clinically detected) or with fruste keratoconus. However, neither corneal ectasia progressed, nor ectasia was induced by RK in the fellow eye.

Corneal ectasias involve complex processes and careful ophthalmic examination should be performed in refractive surgery patients, with special attention to candidates for LASIK.

\section{REFERENCES}

1. Krachmer JH, Feder RS, Belin MW. Keratoconus and related noninflammatory corneal thinning disorders. Surv Ophthalmol. 1984;28(4):293-322.

2. Rabinowitz YS. Keratoconus. Surv Ophthalmol. 1998;42(4):297-319.

3. Holland DR, Maeda N, Hannush SB, Riveroll LH, Green MT, et al. Unilateral keratoconus. Incidence and quantitative topographic analysis. Ophthalmology. 1997;104(9): 1409-13.

4. Khor WB, Wei RH, Lim L, Chan CM, Tan DT. Keratoconus in Asians: demographics, clinical characteristics and visual function in a hospital-based population. Clin Experiment Ophthalmol. 2011;39(4):299-307.

5. Binder PS. Ectasia after laser in situ keratomileusis. J Cataract Refract Surg. 2003;29(12): 2419-29. Comment in: J Cataract Refract Surg. 2004;30(12):2460-1; author reply 2461-2.

6. Kim H, Choi JS, Joo CK. Corneal ectasia after PRK: clinicopathologic case report. Cornea. 2006;25(7):845-8

7. Shaikh S, Shaikh NM, Manche E. latrogenic keratoconus as a complication of radia keratotomy. J Cataract Refract Surg. 2002;28(3):553-5.

8. Randleman JB, Russell B, Ward MA, Thompson KP, Stulting RD. Risk factors and prog nosis for corneal ectasia after LASIK. Ophthalmology. 2003;110(2):267-75.

9. Utine CA, Bayraktar S, Kaya V, Kucuksumer Y, Eren H, Perente l, et al. Radial keratotomy for the optical rehabilitation of mild to moderate keratoconus: more than 5 years' experience. Eur J Ophthalmol. 2006;16(3):376-84.

10. Li X, Rabinowitz YS, Rasheed K, Yang H. Longitudinal study of the normal eyes in unilateral keratoconus patients. Ophthalmology. 2004;111(3):440-6. 